\title{
Mixed-integer Non-linear Programming in Civil Engineering
}

\author{
Stojan Kravanja, Faculty of Civil Engineering, Transportation Engineering and Architecture, \\ University of Maribor, Maribor, Slovenia
}

\begin{abstract}
The paper discusses the Mixed-Integer Non-linear Programming (MINLP) of problems in civil engineering. The MINLP enables the optimization of continuous parameters simultaneously with discrete alternatives. While continuous parameters are in structural optimization structural costs, masses, loads, stresses, resistances and deflections, as well as the discrete alternatives are in most cases defined as different topologies, standard sizes and materials. The continuous parameters are in the models expressed by continuous variables, whilst the discrete alternatives by discrete (0-1) variables. The MINLP optimization of a structure is usually a comprehensive and highly non-linear calculation process. The MINLP approach requires that a structure is generated as an MINLP superstructure including a number of structure alternatives. One of them is the optimal one. For each optimization problem/structure, an MINLP optimization model of the structure must be developed, where the cost or mass objective function of the structure is subjected to structural analysis and dimensioning equality/inequality constraints. The Modified Outer-Approximation/Equality-Relaxation algorithm and a threephase MINLP strategy are applied. Three numerical examples, i.e. the MINLP optimization of a cantilever beam, composite floor and high-pressure penstock are presented at the end of the paper.
\end{abstract}

Keywords: civil engineering, structures, optimization, mixed-integer non-linear programming, MINLP

\section{Introduction}

The study handles the Mixed-Integer Non-Linear Programming (MINLP) of problems in civil engineering. The MINLP enables the optimization of discrete alternatives simultaneously with continuous parameters. It performs the discrete optimization of a number of structural elements (topology), standard dimension optimization (sizes), material optimization (grades) and rounded dimension optimization (dimensions are rounded explicitly on ten millimeters or round centimeters) simultaneously with the continuous optimization of a structure selfmanufacturing costs/mass, internal forces, resistances and deflections. For this reason, the MINLP optimization approach requires that a structure is generated as an MINLP superstructure, which comprises a number of structural alternatives, defined as a combination between various structural elements, discrete dimensions, materials and rounded dimensions. One of the defined structure alternatives is during the MINLP optimization process found as the optimal one.

For the MINLP optimization, an MINLP optimization model of a structure must be developed, see below the general model formulation MINLP-G. The model includes the structure cost or mass objective function $o b j$, and structural analysis and dimensioning constraints $q(x, y) \leq 0$. The latter are determined according to the known principles/rules of the mechanics and standards (Eurocodes). In order to perform the simultaneous continuous and discrete optimizations, continuous variables $x$ and discrete (01) variables $y$ are defined. In MINLP, at least one of the constraints or the objective function is nonlinear.

$$
\begin{array}{r}
\min \\
\text { subjected to } \quad q(x, y) \leq 0 \\
\\
x \in R \\
y \in\{0,1\}
\end{array}
$$

(MINLP-G)

A number of algorithms were developed in the last three decades for the solution of MINLP problems: the GBD method by Benders [1] and Geoffrion [2]; the NBB method by Beale [3], and Gupta and Ravindran [4]; the OA algorithm by Duran and Grossmann [5]; the FT method by Mawengkang and Murtagh [6]; the SLDP method by Olsen and Vanderplaats [7], and Bremicker et al. [8]; the LP/NLP BB method by Quesada and Grossmann [9]; and the ECP method by Westerlund and Pettersson
[10]. The OA extension, the OuterApproximation/Equality Relaxation (OA/ER) algorithm, was later invented by Kocis and Grossmann [11] in order to calculate (non)linear equality constraints. Further extension, the Modified OA/ER algorithm was afterwards introduced in order to solve non-convex problems, see Kravanja and Grossmann [12]. This algorithm was adapted and applied in structural optimization by Kravanja et al. [13-15]. 
For fast calculations of problems, various multilevel MINLP strategies were developed. The strategies perform the optimization of sub-levels rather than the whole problem. Consequently, a lower number of discrete decisions and variables are used in each sub-level when compared to the entire problem. A three-phase MINLP optimization is proposed for structural optimization. The calculation begins with the continuous optimization. The first result is used as a starting point for the further second step, where the discrete optimization of material grades is executed (standard and rounded dimensions are still continuous). After the optimal grades are obtained, the overall discrete material, standard and rounded dimension optimization of a structure is calculated. In this way, the convergence is significantly accelerated. A more detailed information about the multilevel strategies are found in references $[16,17]$.

A number of problems in the area of structural optimization were solved with the presented MINLP approach: e.g. hydraulic steel gates for dams and hydro-power plants by Kravanja et al. [15, 16], steel and aluminum trusses by Šilih et al. [18], timber truss structures by Šilih et al. [19, 20], multi-storey steel frame buildings by Klanšek et al. [21], single-storey industrial steel buildings by Kravanja and Žula [22] and Kravanja et al. [23], composite I-beam structures from concrete and steel by Kravanja and Šilih [24], Klanšek and Kravanja [25, 26], Žula et al. [27] and Kravanja et al. [28] as well as timber-concrete composite floors by Jelušič and Kravanja [29]. A recent research work is also referred in the field of MINLP optimization of project schedules by Klanšek [30] and Cajzek and Klanšek [31].

Three numerical examples are introduced in the paper in order to show the capabilities of the presented MINLP approach, i.e. the small optimization problem of a cantilever beam, the medium optimization problem of a composite floor and the large optimization problem of a high-pressure penstock. GAMS (General Algebraic Modelling System) by Brooke et al. [32] is used for modelling the optimization models. The MINLP optimizations are calculated by the computer program MIPSYN, the extension of PROSYN [12] and TOP [33]. GAMS/CONOPT4 (Generalized reduced-gradient method) [34] and GAMS/CPLEX 12.7 (Branch and Bound method) [35] solvers are used.

\section{MINLP optimization of a cantilever beam (small problem)}

The first example shows the MINLP optimization of a $3.50 \mathrm{~m}$ long laminated timber cantilever beam. The beam supports the self-weight, the uniformly distributed permanent load of $10 \mathrm{kN} / \mathrm{m}(\mathrm{g})$ and the uniformly distributed variable imposed load of 15 $\mathrm{kN} / \mathrm{m}$ (q), see Figure 1. Laminated timber GL24h is considered.

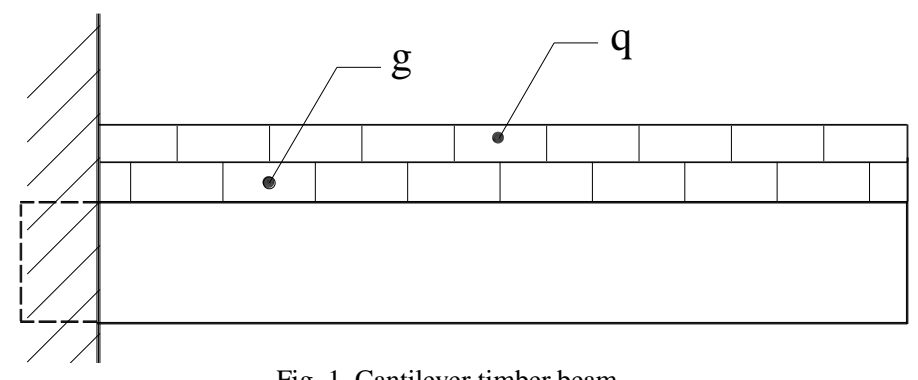

Fig. 1. Cantilever timber beam

The task of the optimization is to calculate the minimal self-manufacturing (material and labor) costs and discrete dimensions of the beam. The optimization model of the cantilever beam is developed. The superstructure of the beam comprises a number of alternatives of even values for the beam height and width. A simple economic objective function is defined. The unit price of the laminated timber considered is $600 \mathrm{EUR} / \mathrm{m}^{3}$ and of the impregnation $125 \mathrm{EUR} / \mathrm{m}^{3}$. The dimensioning constraints (e.g. shear, bending, the lateral-torsional buckling and deflections) are determined according to Eurocode 5 [36].

The minimal self-manufacturing costs of the timber beam yields 446.60 EUR. The obtained discrete dimensions comprise the beam width of 22 $\mathrm{cm}$ and the beam height of $80 \mathrm{~cm}$.
MINLP optimization of a composite floor (medium problem)

The second example presents the MINLP optimization of a $21 \mathrm{~m}$ long composite floor. A concrete slab and welded steel I beams are composed together with shear connectors. The composite floor supports the self-weight and the uniformly distributed imposed load of $5 \mathrm{kN} / \mathrm{m}^{2}$.

The main task to be achieved performing this example, is to find the minimal production costs, material grades and standard dimensions of the composite floor. The superstructure of the floor includes a number of discrete alternatives of steel grades, concrete strengths, reinforcing steel meshes and thicknesses of steel plates. The optimization model of the composite floor defines a cost objective function. The unit prices considered are shown in 
Table 1. The dimensioning constraints (shear, bending, the shear buckling and deflections) are determined in accordance with Eurocode 4 [37].

TABLE 1

Unit prices

\begin{tabular}{lrl}
\hline Structural steel S 235-S 355 & $1.1-1.2$ & $\mathrm{EUR} / \mathrm{kg}$ \\
Reinforcing steel S 400 & 1.3 & $\mathrm{EUR} / \mathrm{kg}$ \\
Concrete C 25/30-C 50/60 & $100-125$ & $\mathrm{EUR} / \mathrm{m}^{3}$ \\
Sheet plate cutting & 7.5 & $\mathrm{EUR} / \mathrm{m}^{1}$ \\
Welding & 10 & $\mathrm{EUR} / \mathrm{m}^{1}$ \\
Anti-corrosion resistant painting (R30) & 25 & $\mathrm{EUR} / \mathrm{m}^{2}$ \\
Paneling & 10 & $\mathrm{EUR} / \mathrm{m}^{2}$ \\
\hline
\end{tabular}

C $25 / 30$
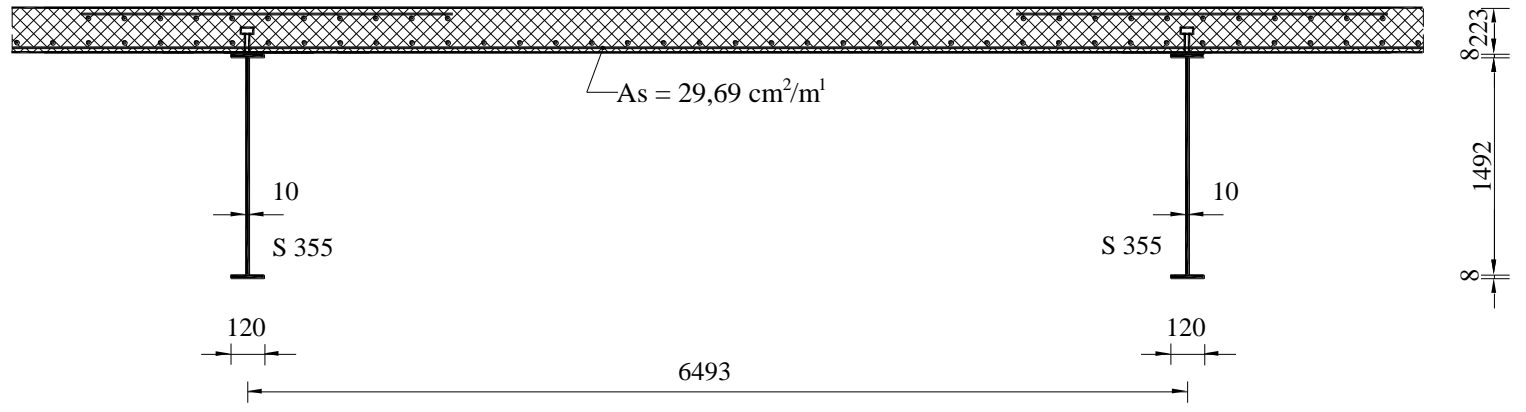

Fig. 2. Optimal composite floor

The minimal production costs of $86.11 \mathrm{EUR} / \mathrm{m}^{2}$ are gained in the $3^{\text {rd }}$ MINLP iteration. All necessary material grades/strengths and standard dimensions are also calculated, see Figure 2.

\section{MINLP optimization of a high-pressure penstock (large problem)}

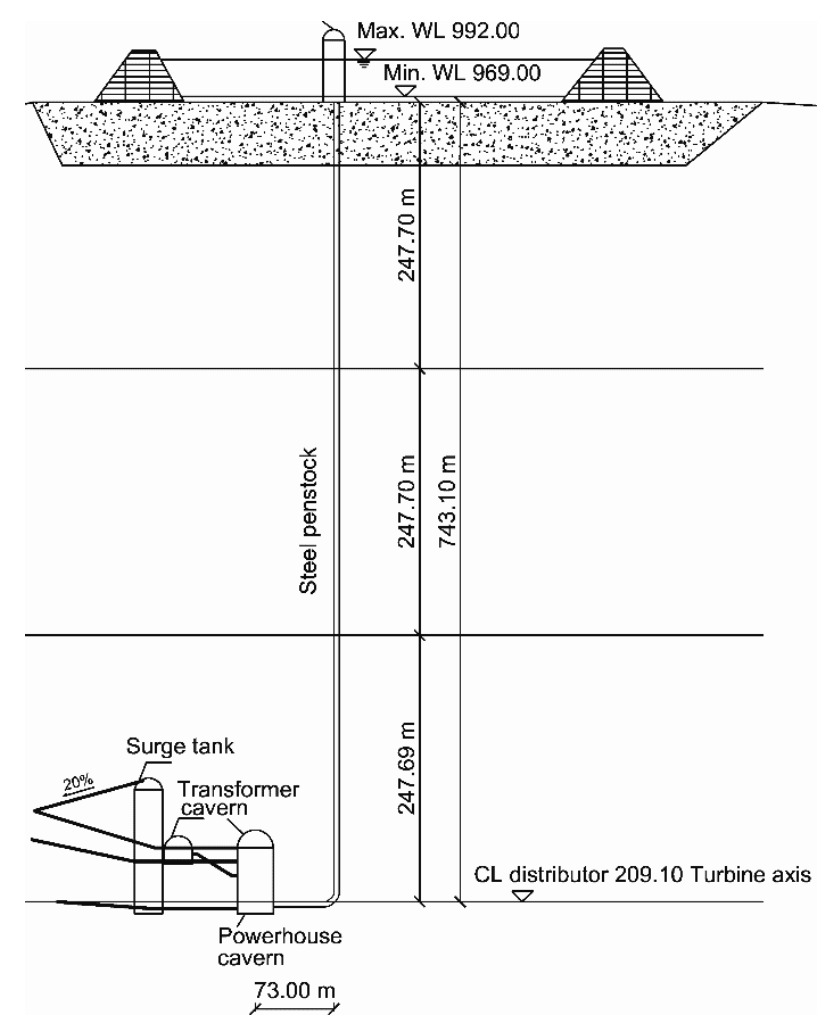

Fig. 3. The vertical variant of the steel penstock Kozjak 
The third example shows the optimization of the high-pressure steel penstock for the pumped storage hydroelectric power plant Kozjak, planned to be constructed $15 \mathrm{~km}$ far from the city of Maribor, Slovenia. The power plant includes already constructed water reservoir of 3 million $\mathrm{m}^{3} .2400 \mathrm{~m}$ long steel penstock will be constructed with the water head of $700 \mathrm{~m}$.
The preliminary calculations and the design for the power plant Kozjak were made by IBE Ljublana in 2011 [38] (the inclined penstock variants) and in 2012 [39] (the vertical penstock). Variants of the penstock were afterwards optimized, see Kravanja [40, 41].

TABLE 2

Optimized longitudinal sections of the vertical penstock Kozjak

\begin{tabular}{|c|c|c|c|c|c|c|c|c|c|}
\hline $\mathrm{x} \quad \mathrm{m}$ & Sect & $\mathrm{p}_{\text {in }} \mathrm{m}$ & $p_{\text {ex }} \quad m$ & $\mathrm{D} \mathrm{m}$ & $\mathrm{t} \quad \mathrm{mm}$ & $L_{\text {sect }} \mathrm{m}$ & & Steel $\Sigma$ mass & $\mathrm{kg}$ \\
\hline 0.00 & 1 & 949.20 & 782.90 & \multirow{5}{*}{3.20} & 55 & 81.00 & \multirow{5}{*}{$\begin{array}{l}8 \\
\text { is } \\
\text { is }\end{array}$} & $\begin{array}{l}\text { pipe: } \\
\text { stiffeners: } \\
\text { total: }\end{array}$ & $\begin{array}{r}357617 \\
23443 \\
381060 \\
\end{array}$ \\
\hline 81.00 & 2 & 883.00 & 733.90 & & 49 & 54.00 & & $\begin{array}{l}\text { pipe: } \\
\text { stiffeners: } \\
\text { total: }\end{array}$ & $\begin{array}{r}212011 \\
14723 \\
226734\end{array}$ \\
\hline 135.00 & 3 & 817.60 & 679.90 & & 46 & 54.00 & & $\begin{array}{l}\text { pipe: } \\
\text { stiffeners: } \\
\text { total: }\end{array}$ & $\begin{array}{r}198847 \\
14089 \\
212936\end{array}$ \\
\hline 189.00 & 4 & 752.10 & 625.90 & & 42 & 54.00 & & $\begin{array}{l}\text { pipe: } \\
\text { stiffeners: } \\
\text { total: }\end{array}$ & $\begin{array}{r}181332 \\
13913 \\
195245\end{array}$ \\
\hline 243.00 & 5 & 686.70 & 571.90 & & 39 & 36.66 & & $\begin{array}{l}\text { pipe: } \\
\text { stiffeners: } \\
\text { total: }\end{array}$ & $\begin{array}{r}114206 \\
9031 \\
123237\end{array}$ \\
\hline \multicolumn{8}{|c|}{ Lower part: } & \multicolumn{2}{|c|}{1139212} \\
\hline 279.66 & 6 & 642.20 & 535.20 & \multirow{5}{*}{3.40} & 61 & 54.00 & \multirow{5}{*}{$\begin{array}{l}\text { O } \\
\text { +⿱ } \\
\text { n }\end{array}$} & $\begin{array}{l}\text { pipe: } \\
\text { stiffeners: } \\
\text { total: }\end{array}$ & $\begin{array}{r}281154 \\
12419 \\
293573 \\
\end{array}$ \\
\hline 333.66 & 7 & 576.70 & 481.20 & & 55 & 54.00 & & $\begin{array}{l}\text { pipe: } \\
\text { stiffeners: } \\
\text { total: }\end{array}$ & $\begin{array}{r}253060 \\
12047 \\
265107 \\
\end{array}$ \\
\hline 387.66 & 8 & 511.30 & 427.20 & & 49 & 54.00 & & $\begin{array}{l}\text { pipe: } \\
\text { stiffeners: } \\
\text { total: }\end{array}$ & $\begin{array}{r}225062 \\
11252 \\
236314 \\
\end{array}$ \\
\hline 441.66 & 9 & 445.80 & 373.20 & & 43 & 54.00 & & $\begin{array}{l}\text { pipe: } \\
\text { stiffeners: } \\
\text { total: }\end{array}$ & $\begin{array}{r}197160 \\
11044 \\
208204\end{array}$ \\
\hline 495.66 & 10 & 380.40 & 319.20 & & 35 & 31.70 & & $\begin{array}{l}\text { pipe: } \\
\text { stiffeners: } \\
\text { total: }\end{array}$ & $\begin{array}{r}93988 \\
6293 \\
100281\end{array}$ \\
\hline \multicolumn{8}{|c|}{ Middle part: } & \multicolumn{2}{|c|}{1103479} \\
\hline 527.36 & 11 & 341.90 & 287.50 & \multirow{5}{*}{3.60} & 45 & 54.00 & \multirow{6}{*}{$\begin{array}{l}n \\
n \\
n\end{array}$} & $\begin{array}{l}\text { pipe: } \\
\text { stiffeners: } \\
\text { total: }\end{array}$ & $\begin{array}{r}218436 \\
10490 \\
228926\end{array}$ \\
\hline 581.36 & 12 & 276.50 & 233.50 & & 35 & 54.00 & & $\begin{array}{l}\text { pipe: } \\
\text { stiffeners: } \\
\text { total: }\end{array}$ & $\begin{array}{r}169428 \\
10150 \\
179578\end{array}$ \\
\hline 635.36 & 13 & 211.00 & 179.50 & & 28 & 54.00 & & $\begin{array}{l}\text { pipe: } \\
\text { stiffeners: } \\
\text { total: }\end{array}$ & $\begin{array}{r}135282 \\
8774 \\
144056 \\
\end{array}$ \\
\hline 689.36 & 14 & 145.60 & 125.50 & & 20 & 54.00 & & $\begin{array}{l}\text { pipe: } \\
\text { stiffeners: } \\
\text { total: }\end{array}$ & $\begin{array}{r}96417 \\
8214 \\
104631\end{array}$ \\
\hline 743.36 & 15 & 78.10 & 69.50 & & 12 & 31.70 & & $\begin{array}{l}\text { pipe: } \\
\text { stiffeners: } \\
\text { total: }\end{array}$ & $\begin{array}{r}33885 \\
4214 \\
38099\end{array}$ \\
\hline 775.06 & 16 & 39.80 & 37.80 & 4.00 & 10 & 9.00 & & $\begin{array}{l}\text { pipe: } \\
\text { stiffeners: } \\
\text { total: }\end{array}$ & $\begin{array}{l}8900 \\
1016 \\
9916\end{array}$ \\
\hline \multicolumn{8}{|c|}{ Upper part: } & \multicolumn{2}{|r|}{705206} \\
\hline Steel pen & ock to & & & & & & & & 947897 \\
\hline
\end{tabular}


The optimization model of the penstock includes the mass objective function of the longitudinal steel sections. The dimensioning constraints for the stability of the penstock are defined in accordance with C.E.C.T. Recommendations [42] including the internal and external water pressure load cases. The dynamic effect of the water hammer is taken into consideration, too.

The structure of the special vertical variant consisting of the $784.06 \mathrm{~m}$ long and $743.10 \mathrm{~m}$ deep penstock is presented in Figure 3. The presented variant in this paper comprises the steel pipe with stiffener rings, designed from three different steel grades: S 355, S 460 and S 690. While the upper part of the penstock which is loaded with minimal water pressure is designed from mild steel S 355 , the lower part loaded with a maximal pressure is proposed to be constructed from high-strength steel S 690. Highstrength steel S 460 is used for the middle pipe part. (In)equality constraints for the stability of the pipe between two rings, for the stability of stiffener rings and for checking the elastic behavior of the steel material are included in the model. The internal diameters $\mathrm{D}$ of the pipe vary from 3.2 to $4.0 \mathrm{~m}$ and the pipe longitudinal sections $\mathrm{L}_{\text {sect }}$ from 9.0 to $81.0 \mathrm{~m}$. While the maximal internal water pressure $p_{\text {in }}$ is 94.92 bars, the maximal external water pressure $p_{e x}$ is 78.29 bars.

The minimal penstock mass of 2947.90 tons is calculated including the pipe thicknesses $t$ from 10 to $61 \mathrm{~mm}$, see Table 2.

\section{Summary}

The study discusses the Mixed-Integer Non-linear Programming (MINLP) of problems in civil engineering. The MINLP performs the optimization of discrete alternatives simultaneously with continuous parameters of structures.

For each optimization problem/structure, a special MINLP superstructure is generated, constructed from various structure alternatives. The task of the optimization is to find a feasible and optimal structure within all alternatives. An extra MINLP optimization model is developed for each structure in GAMS (General Algebraic Modelling System) environment. In the model, the cost or mass objective function of a structure is defined, constrained to structural analysis and dimensioning constraints. The Modified OuterApproximation/Equality-Relaxation (the Modified OA/ER) algorithm, the three-phase MINLP optimization strategy and the computer program MIPSYN are used for the optimization.

Three numerical examples, i.e. the MINLP optimization of a timber cantilever beam, concretesteel composite floor and high-pressure steel penstock are presented at the chapters of the paper. It is proven that the MINLP optimization successfully solves large-scale non-linear and discrete optimization problems of structures in civil engineering.

\section{Acknowledgements}

The author is grateful for the support of funds from the Slovenian Research Agency (program P20129).

\section{References}

1. Benders, J.F. Partitioning Procedures for Solving Mixed-variables Programming Problems. Numer. Math., 1962, No. 4, p. $238-252$.

2. Geoffrion, A.M. Generalized Benders Decomposition. J. Optim. Theory Appl., 1972, No. 10(4), p. $237-260$.

3. Beale, E.M.L. Integer Programming. In: The State of the Art in Numerical Analysis, Academic Press, London, 1977, p. 409-448.

4. Gupta, O.K., Ravindran, A. Branch and bound experiments in convex nonlinear integer programming. Management Science, 1985, No. 31(12), p. 1533-1546.

5. Duran, M.A., Grossmann, I.E. An Outer-Approximation Algorithm for a Class of Mixed-Integer Nonlinear Programs. Math. Prog., 1986, No. 36, p. 307-339.

6. Mawengkang, H., Murtagh, B.A. Solving Nonlinear Integer Programs with Large-Scale Optimization Software, Ann. Oper. Res., 1986, No. 5, p. 425-437.

7. Olsen, G.R., Vanderplaats, G.N. Method for Nonlinear Optimization with Discrete Design Variables. AIAA J, 1989, No. 27(11), p. 1584-1589.

8. Bremicker, M., Papalambros, P.Y., Loh, H.T. Solution of Mixed-Discrete Structural Optimization Problems with a New Sequential Linearization Method. Comput. Struct., 1990, No. 37(4), p. 451-461.

9. Quesada, I., Grossmann, I.E. An LP/NLP Based Branch and Bound Algorithm for Convex MINLP Optimization Problems. Computers Chem. Engng., 1992, No. 16, p. 937-947.

10. Westerlund, T., Pettersson, F. An extended cutting plane method for solving convex MINLP problems. In: European Symposium on Computer Aided Process Engineering-5, Supplement to Computers Chem. Engng, Bled, Slovenia, 1995, p. 131-136.

11. Kocis, G.R., Grossmann, I.E. Relaxation Strategy for the Structural Optimization of Process Flowsheets, Ind. Engng. Chem. Res., 1987, No. 26, p. 1869-1880.

12. Kravanja, Z., Grossmann, I.E. New Developments and Capabilities in PROSYN - An Automated Topology and Parameter Process Synthesizer. Computers Chem. Engng., 1994, No. 18(11/12), p. 1097-1114.

13. Kravanja, S., Kravanja, Z., Bedenik, B.S. The MINLP optimization approach to structural synthesis. Part I: A general view on simultaneous topology and parameter optimization. International Journal for Numerical Methods in Engineering, 1998, No. 43, p. 263-292.

14. Kravanja, S., Kravanja, Z., Bedenik, B.S. The MINLP optimization approach to structural synthesis. Part II: Simultaneous topology, parameter and standard dimension optimization by the use of the Linked two-phase MINLP strategy. International Journal for Numerical Methods in Engineering, 1998, No. 43, p. 293-328.

15. Kravanja S, Kravanja, Z., Bedenik, B.S. The MINLP optimization approach to structural synthesis, Part III: Synthesis of roller and sliding hydraulic steel gate structures. International Journal for Numerical Methods in Engineering, 1998, No. 43, p. $329-364$. 
16. Kravanja, S., Soršak, A., Kravanja, Z. Efficient multilevel MINLP strategies for solving large combinatorial problems in engineering. Optimization and engineering, 2003, No. 1/2, p. 97-151.

17. Kravanja, S., Šilih, S., Kravanja, Z. The multilevel MINLP optimization approach to structural synthesis: the simultaneous topology, material, standard and rounded dimension optimization. Advances in engineering software, 2005, No. 36(9), p. 568-583.

18. Šilih, S., Žula, T., Kravanja, Z., Kravanja, S. MINLP optimization of mechanical structures. American journal of applied sciences, 2008, No 5(1), p. 48-54.

19. Šilih, S., Premrov, M., Kravanja, S. Optimum design of plane timber trusses considering joint flexibility. Engineering structures, 2005, No. 27(1), p. 145-154.

20. Šilih, S., Kravanja, S., Premrov, M. Shape and discrete sizing optimization of timber trusses by considering of joint flexibility. Advances in engineering software, 2010, No. 41(2), p. 286-294.

21. Klanšek, U., Žula, T., Kravanja, Z., Kravanja, S. MINLP optimization of steel frames. Advanced steel construction, 2007, No. 3(3), p. 689-705.

22. Kravanja, S., Žula, T. Cost optimization of industrial steel building structures. Advances in engineering software, 2010, No. 41(3), p. $442-450$.

23. Kravanja, S., Turkalj, G., Šilih, S., Žula, T. Optimal design of single-story steel building structures based on parametric MINLP optimization. Journal of Constructional Steel Research, 2013, No. 81, p. 86-103.

24. Kravanja, S., Šilih, S. Optimization based comparison between composite I beams and composite trusses. Journal of Constructional Steel Research, 2003, No. 59(5), p. 609-625.

25. Klanšek, U., Kravanja, S. Cost estimation, optimization and competitiveness of different composite floor systems. Part 1 , Selfmanufacturing cost estimation of composite and steel structures. Journal of Constructional Steel Research, 2006, No. 62(5), p. 434448.

26. Klanšek, U., Kravanja, S. Cost estimation, optimization and competitiveness of different composite floor systems. Part 2, Optimization based competitiveness between the composite I beams, channel-section and hollow-section trusses. Journal of Constructional Steel Research, 2006, No. 62(5), p. 449-462.

27. Žula, T., Kravanja, S., Klanšek, U. MINLP optimization of a composite I beam floor system. Steel and composite structures, 2016, No. 22(5), p. 1163-1186.

28. Kravanja, S., Žula, T., Klanšek, U. Multi-parametric MINLP optimization study of a composite I beam floor system. Engineering structures, 2017, No. 130, p. 316-335.

29. Jelušič, P., Kravanja, S. Optimal design of timber-concrete composite floors based on the multi-parametric MINLP optimization. Composite structures, 2017, No. 179, p. 285-293.

30. Klanšek, U. Mixed-integer nonlinear programming model for nonlinear discrete optimization of project schedules under restricted costs. Journal of construction engineering and management, 2016, No. 142(3), p. 1-13.

31. Cajzek, R., Klanšek, U. Mixed-integer nonlinear programming based optimal time scheduling of construction projects under nonconvex costs. Tehnički vjesnik : znanstveno-stručni časopis tehničkih fakulteta Sveučilišta u Osijeku, 2016, No. 23(1), p. 9-18

32. Brooke, A., Kendrick, D. and Meeraus, A., GAMS - A User's Guide, Scientific Press, Redwood City, CA, 1988.

33. Kravanja, S., Kravanja, Z., Bedenik, B.S., Faith, S. Simultaneous Topology and Parameter Optimization of Mechanical Structures, In: Proceedings of the First European Conference on Numerical Methods in Engineering, Elsevier, Amsterdam, 1992, p. 487-495.

34. Drudd, A.S. CONOPT - A Large-Scale GRG Code, ORSA J. Comput., 1994, No. 6, p. 207-216.

35. CPLEX User Notes, ILOG inc.

36. Eurocode 5. Design of timber structures, European Committee for Standardization, Brussels, 2004.

37. Eurocode 4. Design of composite steel and concrete structures - Part 1-1: General rules and rules for buildings, European Committee for Standardization, Brussels, 2004.

38. Močnik, I., Kimovec, J. Penstock dimensioning, 3. civil construction design, Penstock, Kozjak PSP, IBE Ljubljana, 2011.

39. Močnik, I. Technical Report, 3. civil construction design, 3/18 Penstock - cavern type, Kozjak PSP, IBE Ljubljana, 2012.

40. Kravanja, S. Optimization of steel penstock in a bored tunnel, In: High performance and optimum design of structures and materials, 2014 International Conference on High performance and optimum design of structures and materials, HPSM/OPTI 2014, WIT transactions on the built environment vol. 137, WIT Press, Southampton, 2014, p. 337-345.

41. Kravanja, S. The optimization of penstock with the recommendations for the design of steel liner and the collaboration of the rock, Variant the verical penstock, The recommendations for the dimensioning and optimization of steel penstock, Kozjak PSP, Faculty of Civil Engineering, University of Maribor, 2012.

42. C.E.C.T. Recommendations for the design, manufacture and erection of steel penstocks of welded construction for hydro electric installations, European Committee for boilermaking and kindred steel structures, Prepared by the »Penstock« Section, 1979. 